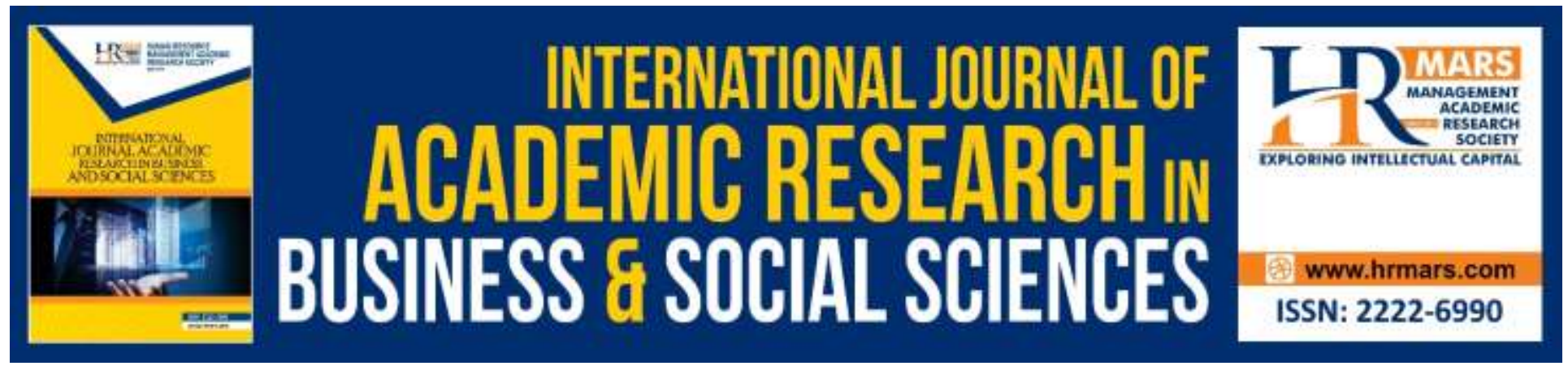

\title{
Analyzing the Direct and Indirect Impact of Budget Deficit and other Factors on GDP in Malaysia
}

Asmawi Hashim, Norimah Rambeli@Ramli, Norasibah Abdul Jalil, \& Emilda hashim

To Link this Article: http://dx.doi.org/10.6007/IJARBSS/v9-i11/6623

DOI: 10.6007/IJARBSS/v9-i11/6623

Received: 12 October 2019, Revised: 30 October 2019, Accepted: 12 November 2019

Published Online: 30 November 2019

In-Text Citation: (Hashim, Ramli, Jalil \& Hashim, 2019)

To Cite this Article: Hashim, A., Ramli, N. R., Jalil, N. A., \& Hashim, E. (2019). Analyzing the direct and indirect impact of budget deficit and other factors on GDP in Malaysia. International Journal of Academic Research in Business and Social Sciences, 9(11), 1025-1040.

Copyright: (C) 2019 The Author(s)

Published by Human Resource Management Academic Research Society (www.hrmars.com)

This article is published under the Creative Commons Attribution (CC BY 4.0) license. Anyone may reproduce, distribute, translate and create derivative works of this article (for both commercial and non-commercial purposes), subject to full attribution to the original publication and authors. The full terms of this license may be seen

at: http://creativecommons.org/licences/by/4.0/legalcode

Vol. 9, No. 11, 2019, Pg. 1025 - 1040

http://hrmars.com/index.php/pages/detail/IJARBSS

JOURNAL HOMEPAGE

Full Terms \& Conditions of access and use can be found at http://hrmars.com/index.php/pages/detail/publication-ethics 


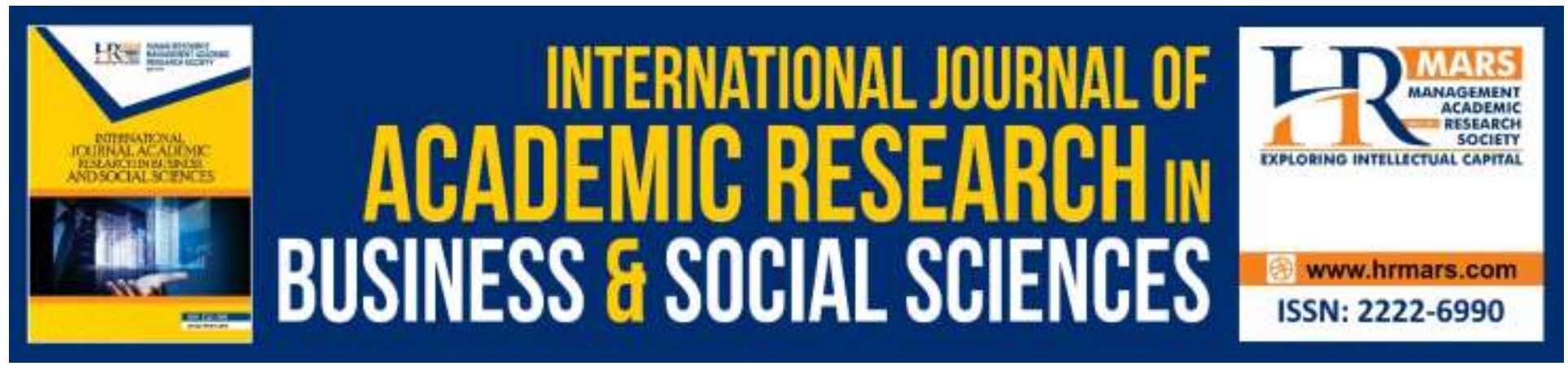

\title{
Analyzing the Direct and Indirect Impact of Budget Deficit and other Factors on GDP in Malaysia
}

\section{Asmawi Hashim, Norimah Rambeli@Ramli, Norasibah Abdul Jalil, \& Emilda hashim \\ Lecturer in Economics, Department of Economics, UniversitiPendidikan Sultan Idris (UPSI),}

Perak.

\begin{abstract}
The objective of this study is to analyze the impact of budget deficit and other factors on GDP in Malaysia. The data used in this study are yearly series data from 1987-2016. This study also uses Statistical Packages for the Social Sciences (SPSS) software for data analysis purposes. For the purpose of establishing a budgeting model, this study uses Ordinary Least Square (OLS). The findings suggest that there is a significant and positive relationship between all the variables used, namely budget deficit, investment, national saving, real effective exchange rate and real interest rate with gross domestic product (GDP). Therefore, based on the findings, this study hope the result can be imply into a policy to help the government to improve economic growth in Malaysia in the future. Thus, Malaysia will be able to achieve the status of a developed country and more efficiently by the year 2020.
\end{abstract}

Keywords: Economic Growth, Budget Deficit, Ordinary Least Square

\section{Introduction}

Malaysia is one of the ASEAN countries that experience high economic growth. This miracle start in 1980 following government action develop the industrial sector and practice "Dasar Pandang KeTimur" through cooperation and economic combination with the most advanced Asian country namely Japan. After that, government effort liberated domestic sector to attracting entry of foreign investment on the other hand seen had further enliven output growth in 1990.

Analysis on economic growth represents one of the important aspects in macroeconomic theory. Basically, analysis economic growth disclose about economic activity of a country in the long run. Hence, economic growth can be defined as measurement towards economic development performance one country through individual items total production growth, infrastructure development, number of school expansion, economic expansion of other sectors, social development and development of economic activity like goods and services issued to 
society increased and consequently social welfare to one country also increase (Sadono and Aslam, 1999). Therefore, economic growth approach mean output growth in country.

The importance of saving in the process of achieving higher economic growth has been debatable and long recognized by economist and policy maker in all countries in this world. In order to maintain a country's capital stock and sustain the standard of living, a large flow of saving must be generated and transferred into productive investment. In the study undertaken by Yen (1993), an important prerequisite for capital formation and hence, national development is the mobilization of savings. Economics growth can be sustained only if resources are mobilized efficiently and transform into productive activities. The nation's rapid growth is largely due to the high capital growth, which in turn depends on the national saving. Moreover, it is righteous to suggest that national saving is the pump primer that propels the nations fast pace economic growth. The high national saving rate allows domestic investment to take place with less dependability on foreign capital injection. While it is instantly recognized that there is exist a strong positive relationship between growth and national saving.

However, the rate of national saving is still depending on several factors. One of the factors that will effect national saving is a budget deficit. The budget deficits arise when the government spends beyond their means. Budget deficit have long been debatable issue over their consequences on the economy, which would include the impact on macroeconomic variables as well as its effect on the long-term economic growth. How budget deficits affect growth rate of national savings is, depending on economic planning for the country. As economic planning, reliance on the imposition of taxes and government spending is a reasonable step that is often played by all countries in the world to increase the savings of his country, and directly drive sustainable economic growth. In spite of this, it should be noted, the imposition of tax, seen as a burden to the people, and reduced government spending for development will also give the effect of unbalanced development of the country. Such things become a "problem" to economic planner and give great blow to the credibility of the leader of a country. On the other hand, the former member of the Council of Economic Adviser, Nordhaus (1996) in his writing about "Budget Deficit and National Saving" stressed out that low saving is not a problem (for America's case). The problem is that wasteful government programs which will crowding out productive ones. In this case, what was the rationale for balancing the budget? Appropriate approach should be taken to implement and enhance the performance of the economy and need to take action to improve the damaged - at least the government of each country has its own determination of whether a traditional or more conventional. Again, William D. Nordhaus highlighted that government are different things to different people, but to economist government are responsible for three roles: stabilizing the economy, ensuring a fair distribution of income and promoting economic efficiency. To accomplish these responsibilities, the government must consider its impact on society and economic development in the future if that is not fully implemented. But, the government should take the initiative if the obligation should be implemented; the budget deficit (the effect of tax reduction: for the purpose of increasing disposable incomes of the population, and increased government spending: for the purpose of development of the country) will occur and affect the rate of economic growth in the future. 
Nevertheless, the extent of the impact on the economy of a country should be reviewed and evaluated.

In general, Saad and Kalakech (2009) in their study expressed the issue about budget deficit, which is representing a demand for funds by the government. This demand must be met from an excess of domestic saving over investment and by borrowing from abroad, taxes, or the use of monetary policy. The increasing budget deficit will drive up the interest rates since treasury bids for funds to finance the budget. In turn, high interest rate may occur and crowd out private investment spending. This situation was called crowding out effect. If this occurs in an economy on an ongoing basis, it will form a continuous deficit budgets or classified it as sustained budget deficit. With sustainably increasing or prolong budget deficit, it is important to analyzed the behavior of it and detect if these deficits have a significant impact on economic through the impact of national saving.

The other important issue to discuss is the impact of other variables that also looked can give an impact on national saving directly or indirectly. The other factors that are related to the national saving growth are money supply, real interest rate and real exchanged rate. From the study by Gale and Orszag (2004) highlighted three views of the impact of budget deficit on national savings through other factors. First is from the views of David Ricardo thought (called Ricardian Equivalent Proposition), second is for small open economic evaluation or also known as perfect capital mobility, and the third highlighted by Elmendorf and Mankiw called conventional views. From these three views, shows that the impact on national savings variation was not only directly from the variation of budget deficit but also comes from other factors. This study will look at into deep the direct and indirect impact of all these variables on national savings for all the five countries to investigate what are the main issue occurs.

\section{Literature Review}

The study is generally to see the relationship between economic growth, budget deficit, investment, national saving, real effective exchange rate and real interest rate in Malaysia for a period of 30 years from 1987 to 2016. In addition, this study will also look at the relationship between a dependent variable of economic growth with independent variables namely budget deficit, investment, national saving, real effective exchange rate and real interest rate. Selected recent studies will be reviewed to see similarities and differences in comparing the studies that will be conducted with previous studies that have been produced.

In Ricardian Equivalent proportion - (the argument was first advanced by the nineteen century economist, David Ricardo, although he expressed some reservations about its applicability to real-world situations. The word "equivalent" refers to the idea that if Ricardian equivalent is true, taxes and government borrowing have equivalent effect on the economy)Ricardian tries to show the relationship between tax and national saving. Tax is one of the source of budget. Some economists argue that the positive effect of increased current income and the negative effect of decreased future income on desired consumption should exactly cancel so that the overall effect of a current tax cut on consumption is zero. The idea that tax cuts do not affect desired consumption and therefore also do not affect desired national saving. Even though tax 
only give a small effect to the budget but it gives a big impact to the government spending or consumption which will effects the national saving.

As an alternative and perhaps more direct way to increase the national saving rate is by increasing the amount that the government saves; in other word, the government should try reduce its deficit or increase its surplus. Our analysis of the "twin deficit" (federal budget deficit and the current account deficit) debate indicated that reducing the deficit by reducing government purchases will lead to more national saving. Many economists also argue that raising taxes to reduce the deficit will also increase national saving by leading people to consume less. However, believers in Ricardian equivalence contend that tax increase without changes in current or planned government purchases won't effects consumption or national saving.

Theoretically, economist do not encourage large budget deficit because of their detrimental effect to long-term growth and stability of an economy. Based on Economics Review published by Economics Division Public Bank Bhd (Malaysia), Oct 2002 - a large budget deficit leads to lower national saving, lower investment, and a trade deficit. In the long-run, large deficit could lead to a smaller capital accumulation and larger foreign debt.

By referring to the Ricardian-equivalent proportion, Hoover (1992) explained that tax reforms that would increase the rate of return to saving would increase the fed deficit by reducing tax revenues, and they would probably have only a negligible positive impact on household saving. He also proposed five tax reform proposals intended to increase household saving including substituting consumption taxes for income tax, removing tax incentives, introducing new saving incentives, introducing a preferential tax rate for capital gains and reducing personal income tax. According to him, in reconsidering the issue of US saving, he concludes that the most direct way to raise national saving is still to reduce the fed deficits by either cutting spending and/or increasing taxes. Ricardo tries to show the relationship between tax and national saving. Tax is one of the sources of budget. Some economists argue that the positive effect of increased current income and the negative effect of decreased future income on desired consumption should exactly cancel so that the overall effect of a current tax cut on consumption is zero. The idea that tax cuts do not affect desired consumption and therefore also do not affect desired national saving. Even though tax only give a small effect to the budget but it gives a big impact to the government spending/ consumption which will effects the national saving.

Theoretically, economist do not encourage large budget deficit because of their detrimental effect to long-term growth and stability of an economy. Based on Economics Review (Malaysia), (2002) - a large budget deficit leads to lower national saving, lower investment, and a trade deficit. In the long run, large deficit could lead to a smaller capital accumulation and larger foreign debt. What is the reasoning behind this focus? The major concerns are: (1) that high government dis-saving depresses domestic saving, reduces capital formation, lowers the growth of potential output, and reduces consumption opportunities in the future; (2) that a high deficit may lead to an explosive government debt as the interest to service the debt grows faster than national income; and (3) that the high government deficit will put the country at a competitive disadvantage with other countries. Few economists today would add (4) using fiscal policy to 
stabilize the business cycle in the short run, because that task is more appropriately handled by monetary policy.

The results of Pradhan G. and Upadhyaya (2001) empirical analysis suggest that an increase in government budget deficits tend to reduce national savings. They utilized the annual time series USA data from 1967 to 1996. From their study they base on the model draws from both Classical and Keynesian approaches includes budget deficits, money supply, real exchange rate, and the proportion of working age population to total population to explain national saving. After examining the time series properties of the data an error correction model is estimated. The overall result suggested that an increase in government budget deficit tend to reduce national saving.

Cebula, Hung and Menage (1996), in their study on Ricardian Equivalent, budget deficits and savings in US found that structural deficits elicit increased saving but cyclical deficit do not. Thus, findings indicate support for a partially Ricardian Equivalent world: saving only partially offsets budget deficits.

According to Barro (1974) he argues that federal budget deficits are irrelevant to the level of national saving because increase in private saving will neutralize federal budget deficit. Barro also study in advance on Ricardian Equivalence view about the relationship between budget deficit and national saving. The key issue is the response of private saving to a change in the deficit. If private saving rises by the same amount as government saving falls by the same amount as the deficit rises, then there is no change in national saving and no further adjustment would be required or expected. Under this hypothesis, we understand that deficits are fully offset by increase in private saving and have no effect on national saving, interest rate, exchange rates, future domestic production, or future national income.

In the different time horizon, budget deficit can make the same decision on the national saving: reducing national saving. In both the short run and the long run, deficits reduce national saving and increase aggregate demand. In the slack economy, a short-term boost to aggregate demand can improve economic prospect by encouraging people to spend more and firms to use more of their existing capacity. Over this shorter horizon, the economy is sometimes well below full employment of labour and capital. Under those circumstances, a rise in the deficit can provide a welcome boost to aggregate demand and encourage increased use of existing labour and capital, giving the economy a short-term boost. In the long run, a key to rising future national income is higher national saving and national investment, which deficits inhibit. The typical assumption during this horizon is that the economy fully employs existing labour and capital. Under those circumstances, the only way to raise economic growth is to expand the economy's capacity to produce income at home and abroad. By reducing national saving, deficits hinder that ability.

According to Arestis and Resende (2015), if government budget deficit changes relative prices in an economy, the current account balance would be worse by triggering substitution between national and foreign savings. Their study focuses on the relationship between fiscal policy, the real exchange rate, national and foreign savings and investment. 
In the work of SidratJilaniet.all (2013) there were various factors that affected national savings in the country of Pakistan including GDP, inflation, fiscal deficit and rate of interest. The study was based on secondary data of the 1973-2011 periods. All variables used included interest rate are found stationary except the one variable is age dependency ratio. For interest rate, its $t$ value was found 0.13 which show insignificant impact on national savings, hence its hypothesis was rejected while coefficient analysis shows the negative relationship between rate of interest and national savings. Their study entails co-integration and technique that were used to find the long and short turn equilibrium among the variables. Based on the finding the Pakistan government should not rely on manipulation of interest rate in order to boost national savings. Hence, this study of Pakistan may or may not be difference in term of finding and implication for present study of ASEAN members countries.

There was a study done by Ogbokor and Samahiya (2014) on the determinants of savings in Namibia through the use of co-integration and error correction mechanism for the period of 1991-2012. They used quarterly and annual macroeconomics data sets. In their finding, deposit interest rate, financial deepening (measured by broad money supply as a ratio of GDP), as well as past income were not helpful in explaining savings behaviors and decision in Namibia. Therefore, it is advisable for the government of Namibia to implement macroeconomics policies in its economy that would lead to general improvement in income level, while discouraging high population growth, if this country is really enthusiastic about promoting savings.

Tang ChorFoon (2008) undertook a study to review the role of foreign direct investment (FDI) and exports on economic growth in Malaysia for the period 1970 to 2006. Researchers use the Johansen co-integration method to test the existence of long-term relationships and the Error Correction Vector Model VECM) and the Granger Cause Test to test short-term and long-term causal relationship. The empirical results of the study found that there was a long-term relationship between economic growth with both variables namely FDI and export. Similarly, the results obtained from OLS Dynamics which FDI and exports are positively related to economic growth. Furthermore, the results of this study are supported by the Granger's causal test which has a two-way relationship between economic growth and its determinants. Thus, this shows that FDI and exports are the main drivers of Malaysia's economic growth.

Haq (2012) conducted a study to investigate the impact of investment on economic growth in Pakistan for 30 years from 1981 to 2010. Independent variables used are private investment, public investment and foreign direct investment (FDI). This study uses multiple regression techniques and the findings suggest that all independent variables are significant and have a positive impact on economic growth. Whereas, the results from the granger causality test show that there is a two-way relationship between the dependent variable of Gross Domestic Product (GDP) and public investment. However, between GDP and private investment there is only one-way relationship. In addition, studies conducted by Sial, Hashmi and Anwar (2010) using the Autoregressive Vector Approach (VAR) also show that in the long run private investment and public investment have a positive impact on economic growth.

Turan and Gjergji (2014) conducted a study in Albania using annual data from 1992 to 2012 for the Gross Domestic Product (GDP), domestic savings and foreign direct investment (FDI) 
on economic growth. The results of the study by the Johansen Co-integration Test suggest that saving and economic growth are a combination of which it demonstrates the existence of a stable long-term equilibrium relationship. This is in line with the findings of Nurudeen (2010) study conducted in Nigeria for 38 years from 1970 to 2007 that savings and growth are co-managing and long-term relationships. Meanwhile, research conducted by Jagadeesh (2015) in Botswana using the Auto Regressive Distributed Lagged (ARDL) and Dynamic Ordinary Least Square (DOLS) approach also found that there was a significant relationship between saving and economic growth and it was supported by HarrodDomar Growth Model.

A study conducted by Jelilov (2016) to study the impact of interest rates on economic growth in Nigeria for 24 years from 1990 to 2013 using the Ordinary Least Square (OLS) method found that interest rates had a slight impact on economic growth. However the growth can be improved by lower the interest rate which will increase the investment. The results of this study coincide with the findings obtained by Udoka and Anyingang (2012).

Habib, Mileva and Stracca (2016) conducted a study to examine the impact of movements in real exchange rates on economic growth for 150 countries (post Bretton Woods) from 1970 to 2010. Overall, from the analysis using the Ordinary Least Square (OLS) method found that the real exchange rate was crucial to economic growth in the developing economy but for the advanced economies it did not have a significant impact, where this conclusion was confirmed and supported by Rodrik (2008).

Ping (2011) analysed the effects of foreign exchange rates on economic growth in 29 Chinese provinces using data panels from 1987 to 2008. Data analysed using the GMM system estimation approach and the results suggest that the increase in real exchange rates has a negative impact on economic growth where it is higher on the coast than in the interior and this contributes to the reduction of per capita Gross Domestic Product (GDP) per capita between two types of provinces.

The results of the previous analysis showed that all variables had an impact on economic growth in all research study countries. Therefore, these variables will be preserved and used in this study in order to achieve the ultimate goal of this study.

\section{Formation of Specification Model}

In this study, data collected and used is secondary data which is a series of time data for 30 years from 1987 to 2016 . The formation of the specification model for this study is as follows:

$$
Y_{t}=f\left(B D_{t}, I_{t}, N S_{t}, R E E R_{t}, R I R_{t}\right)
$$

Where,

$$
\begin{array}{ll}
Y_{t} & =\text { Gross Domestic Product (GDP) } \\
B D_{t} & =\text { Budget deficit } \\
I_{t} & =\text { Investment } \\
N S_{t} & =\text { National saving }
\end{array}
$$




$$
\begin{array}{ll}
R E E R_{t} & =\text { Real effective exchange rate } \\
R_{\text {I }} & =\text { Real interest rate }
\end{array}
$$

Based on the theory and the results of the previous studies that have been done, the order and the size of the desired parameters can be determined. Because there is a unit difference between the variables then the data has been changed to linear form for budgeting purposes and avoids the problem of specs in the model. The following is a linear model for a Gross Domestic Product that has been set up in the Multiple Regression Model where the second smallest power method can be used: -

$\ln Y_{t}=\alpha_{0}+\alpha_{1} \ln B D_{t}+\alpha_{2} \ln I_{t}+\alpha_{3} \ln N S_{t}+\alpha_{4} \ln R E E R_{t}+\alpha_{5} \ln R I R_{t}+\varepsilon_{t}$

Where,

$$
\begin{array}{ll}
Y_{t} & =\text { Gross Domestic Product (GDP) } \\
\ln B D_{t} & =\text { Budget deficit } \\
\ln I_{t} & =\text { Investment } \\
\ln N S_{t} & =\text { National saving } \\
\ln R E E R_{t} & =\text { Real effective exchange rate } \\
\ln R I R_{t} & =\text { Real interest rate } \\
t & =\text { Monthly data from January } 1987 \text { to December } 2016 \\
\varepsilon_{t} & =\text { Error term } \\
\alpha_{0} & =\text { Constant } \\
\alpha_{1} \alpha_{2} \alpha_{3} \alpha_{4} \alpha_{5} & =\text { Parameter }
\end{array}
$$

\section{Result}

\section{Estimation Model Obtained}

$$
\begin{aligned}
& G D \hat{P}_{t}=46.066+0.14 \hat{0} B D_{t}-0.02 \hat{7} I_{t}-0.35 \hat{4} N S_{t}-3.76 \hat{8} R E E R_{t}-0.01 \hat{0} R I R_{t} \\
& \begin{array}{llllll}
S_{e} & =(3.400) & (0.074) & (0.064) & (0.452) & (0.541)
\end{array} \\
& \text { Ujian } t=(13.551)(1.885) * * * *(-0.422) * *(-0.782) * * *(-6.965) * * * * *(-0.231) * \\
& R^{2} \quad=0.848 \\
& \text { Ujian } F=12.246 \\
& D_{w} \quad=0.845
\end{aligned}
$$

and the notation is as follows

$$
\begin{aligned}
& =\text { Important at } 99 \% \text { confidence level } \\
& =\text { Important at } 93 \% \text { confidence level } \\
& =\text { Important at } 56 \% \text { confidence level } \\
& =\text { Important at } 32 \% \text { confidence level }
\end{aligned}
$$

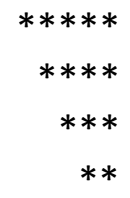




$$
=\text { Important at } 18 \% \text { confidence level }
$$

The results show that a $1 \%$ increase in the budget deficit $\left(B D_{t}\right)$ will increase by $14 \%$ of economic growth measured by Gross Domestic Product $\left(G D P_{t}\right)$ at a 93 percent confidence level. However, an increase of $1 \%$ in investment $\left(I_{t}\right)$ will decrease $2.7 \% G D P_{t}$ at the 32 percent confidence level. Similarly, the $1 \%$ increase in national saving $\left(N S_{t}\right)$ will reduce by $35.4 \% G D P_{t}$ at the 56 percent confidence level. Subsequently, an increase of $1 \%$ in real effective exchange rate $\left(R E E R_{t}\right)$ and real interest rate $\left(R I R_{t}\right)$ will decrease $376.8 \%$ and $1 \% G D P_{t}$ at the 99 and 18 percent confidence level respectively. All independent variables are important in influencing the increase and decrease of $G D P_{t}$ in Malaysia.

The determining value $\left(R^{2}\right)$ obtained from the analysis is equivalent to 0.718 which is a $71.8 \%$ change in the dependent variable $G D P_{t}$ can be explained by independent variables $B D_{t}, I_{t}, N S_{t}, R E E R_{t}, R I R_{t}$. As a result of this study, it was found that the factors $B D_{t}, R E E R_{t}$ used were significant at the confidence level of more than $95 \%$ except for factors $I_{t}, N S_{t}, R I R_{t}$ in which each of these factors was significant at the confidence level of more than $15 \%$. Therefore, independent variables $B D_{t}, I_{t}, N S_{t}, R E E R_{t}, R I R_{t}$ are important in describing the dependent variable $G D P_{t}$.

\section{Statistical Criteria}

Based on statistical criteria, there are two tests conducted on the Individual Test (T-test) and Ftest (Model Fiction Test) test.

\section{Individual Significance Test (T-test)}

Table 4.1: Individual Significant Test (T-test)

\begin{tabular}{|c|c|c|c|c|}
\hline Variables & Hyphothesis & Statistical test & Critical area & Conclusion \\
\hline $\begin{array}{l}\text { Budget } \\
\text { deficit } \\
\left(B D_{t}\right)\end{array}$ & $\begin{array}{l}H_{0}: \beta_{1}=0 \\
H_{1}: \beta_{1} \neq 0\end{array}$ & $\begin{aligned} t^{*} & =\frac{\hat{\beta}_{1}-\beta_{1}}{\operatorname{Se}\left(\hat{\beta}_{1}\right)} \\
t^{*} & =\frac{0.140-0}{0.074} \\
t^{*} & =1.885\end{aligned}$ & $\begin{array}{l}t=(\alpha / 2, N-K) \\
t=0.05 / 2,30-6 \\
t=0.025,24 \\
t= \pm 2.064\end{array}$ & $\begin{array}{l}t^{*}<t \text {, then accept } H_{0} \text {. } \\
\text { This means that } \\
\text { budget deficit }\left(B D_{t}\right) \\
\text { variables are not } \\
\text { important } \\
\text { explaining the gross } \\
\text { domestic product } \\
\left(G D P_{t}\right) \text { at a } 95 \\
\text { percent confidence } \\
\text { level. }\end{array}$ \\
\hline
\end{tabular}


INTERNATIONAL JOURNAL OF ACADEMIC RESEARCH IN BUSINESS AND SOCIAL SCIENCES Vol. 9, No. 11, November, 2019, E-ISSN: 2222-6990 @ 2019 HRMARS

\begin{tabular}{|c|c|c|c|c|}
\hline $\begin{array}{c}\text { Investment } \\
\qquad\left(I_{t}\right)\end{array}$ & $\begin{array}{l}H_{0}: \beta_{1}=0 \\
H_{1}: \beta_{1} \neq 0\end{array}$ & $\begin{array}{l}t^{*}=\frac{\hat{\beta}_{1}-\beta_{1}}{\operatorname{Se}\left(\hat{\beta}_{1}\right)} \\
t^{*}=\frac{-0.027-0}{0.064} \\
t^{*}=-0.422\end{array}$ & $\begin{array}{l}t=(\alpha / 2, N-K) \\
t=0.05 / 2,30-6 \\
t=0.025,24 \\
t= \pm 2.064\end{array}$ & $\begin{array}{l}t^{*}<t \text {, then accept } H_{0} \text {. } \\
\text { This means that } \\
\text { investment }\left(I_{t}\right) \\
\text { variables are not } \\
\text { important for } \\
\text { explaining the gross } \\
\text { domestic product } \\
\left(G D P_{t}\right) \text { at a } 95 \\
\text { percent confidence } \\
\text { level. }\end{array}$ \\
\hline $\begin{array}{c}\text { National } \\
\text { saving } \\
\left(N S_{t}\right)\end{array}$ & $\begin{array}{l}H_{0}: \beta_{1}=0 \\
H_{1}: \beta_{1} \neq 0\end{array}$ & $\begin{array}{l}t^{*}=\frac{\hat{\beta}_{1}-\beta_{1}}{\operatorname{Se}\left(\hat{\beta}_{1}\right)} \\
t^{*}=\frac{-0.354-0}{-0.452} \\
t^{*}=-0.782\end{array}$ & $\begin{array}{l}t=(\alpha / 2, N-K) \\
t=0.05 / 2,30-6 \\
t=0.025,24 \\
t= \pm 2.064\end{array}$ & $\begin{array}{l}t^{*}<t \text {, then accept } H_{0} \text {. } \\
\text { This means that } \\
\text { national saving }\left(N S_{t}\right) \\
\text { variables are not } \\
\text { important for } \\
\text { explaining the gross } \\
\text { domestic product } \\
\left(G D P_{t}\right) \text { at a } 95 \\
\text { percent confidence } \\
\text { level. }\end{array}$ \\
\hline $\begin{array}{c}\text { Real } \\
\text { effective } \\
\text { exchange } \\
\text { rate } \\
\left(R E E R_{t}\right)\end{array}$ & $\begin{array}{l}H_{0}: \beta_{1}=0 \\
H_{1}: \beta_{1} \neq 0\end{array}$ & $\begin{array}{l}t^{*}=\frac{\hat{\beta}_{1}-\beta_{1}}{\operatorname{Se}\left(\hat{\beta}_{1}\right)} \\
t^{*}=\frac{-3.768-0}{0.541} \\
t^{*}=-6.965\end{array}$ & $\begin{array}{l}t=(\alpha / 2, N-K) \\
t=0.05 / 2,30-6 \\
t=0.025,24 \\
t= \pm 2.064\end{array}$ & $\begin{array}{l}t^{*}>t \text {, then reject } H_{0} \text {. } \\
\text { This means that real } \\
\text { effective exchange } \\
\text { rate }\left(R E E R_{t}\right) \text { variables } \\
\text { are important for } \\
\text { explaining the gross } \\
\text { domestic product } \\
\left(G D P_{t}\right) \text { at a } 95 \\
\text { percent confidence } \\
\text { level. }\end{array}$ \\
\hline $\begin{array}{l}\text { Real } \\
\text { interest } \\
\text { rate } \\
\left(R I R_{t}\right)\end{array}$ & $\begin{array}{l}H_{0}: \beta_{1}=0 \\
H_{1}: \beta_{1} \neq 0\end{array}$ & $\begin{array}{l}t^{*}=\frac{\hat{\beta}_{1}-\beta_{1}}{\operatorname{Se}\left(\hat{\beta}_{1}\right)} \\
t^{*}=\frac{-0.010-0}{0.043} \\
t^{*}=-0.231\end{array}$ & $\begin{array}{l}t=(\alpha / 2, N-K) \\
t=0.05 / 2,30-6 \\
t=0.025,24 \\
t= \pm 2.064\end{array}$ & $\begin{array}{l}t^{*}<t \text {, then accept } H_{0} \text {. } \\
\text { This means that real } \\
\text { interest rate }\left(R I R_{t}\right) \\
\text { variables are not } \\
\text { important for } \\
\text { explaining the gross } \\
\text { domestic product }\end{array}$ \\
\hline
\end{tabular}


INTERNATIONAL JOURNAL OF ACADEMIC RESEARCH IN BUSINESS AND SOCIAL SCIENCES

\begin{tabular}{|l|l|l|l|}
\hline & & & $\begin{array}{l}\left(G D P_{t}\right) \text { at a } 95 \\
\text { percent confidence } \\
\text { level. }\end{array}$ \\
\hline
\end{tabular}

\section{Model Fiction Test (F-test)}

Table 4.2: Model Matching Probability Test (F-test)

\begin{tabular}{|c|c|c|c|c|}
\hline Variable & Hyphothesis & Statistical Test & $\begin{array}{c}\text { Critical } \\
\text { Area }\end{array}$ & Conclusion \\
\hline $\begin{array}{c}\text { Estimation } \\
\text { model }\end{array}$ & $\begin{aligned} H_{0} & : \alpha_{1}=\alpha_{2}=\alpha_{3} \\
& =\alpha_{4}=\alpha_{5}=0\end{aligned}$ & $\begin{aligned} F^{*} & =\frac{E S S / d f}{R S S / d f} \\
F^{*} & =\frac{5.008 / 5}{1.963 / 24} \\
F^{*} & =\frac{1.002}{0.082} \\
F^{*} & =12.246\end{aligned}$ & $\begin{array}{l}F_{\alpha}, V_{1}, V_{2} \\
0.05, K-1, \\
N-K \\
0.05,5,24 \\
=2.62\end{array}$ & $\begin{array}{l}F^{*}>F_{\alpha}, V_{1}, V_{2} \text {, } \\
\text { then reject } H_{0} \text {. } \\
\text { All the } \\
\text { independent } \\
\text { variables are } \\
\text { good at } \\
\text { explaining the } \\
\text { dependent } \\
\text { variable at the } \\
95 \text { percent } \\
\text { confidence } \\
\text { level. }\end{array}$ \\
\hline
\end{tabular}

\section{Econometric Criteria}

Based on the econometric criteria, there are three tests carried out, namely autocorrelation, heterocedasticity and multicolinearity.

\section{Autocorrelation}

The autocorrelation problem can be known whether or not the budget model is taking into account DW (Durbin Watson) results obtained at $1 \%$ and $5 \%$ significance levels. The findings of the study showed that at the significance level of $1 \%$ was a test failed and at the $5 \%$ significance level there was positive autocorrelation. 
INTERNATIONAL JOURNAL OF ACADEMIC RESEARCH IN BUSINESS AND SOCIAL SCIENCES Vol. 9, No. 11, November, 2019, E-ISSN: 2222-6990 @ 2019 HRMARS

\section{Heterocedasticity}

Table 4.3: Heterokedasticity

\begin{tabular}{|c|c|c|c|c|}
\hline Variable & Hyphothesis & Statistical Test & $\begin{array}{c}\text { Critical } \\
\text { Area }\end{array}$ & Conclusion \\
\hline $\begin{array}{c}\text { Estimation } \\
\text { model }\end{array}$ & $\begin{array}{l}H_{0}: \alpha_{1}=\alpha_{2}=\alpha_{3} \\
\quad=\alpha_{4}=\alpha_{5}=0\end{array}$ & $\begin{aligned} F^{*} & =\frac{E S S / d f}{R S S / d f} \\
F^{*} & =\frac{5.008 / 5}{1.963 / 24} \\
F^{*} & =\frac{1.002}{0.082} \\
F^{*} & =12.246\end{aligned}$ & $\begin{array}{l}F_{\alpha}, V_{1}, V_{2} \\
0.05, K-1, \\
N-K \\
0.05,5,24 \\
=2.62\end{array}$ & $\begin{array}{l}F^{*}>F_{\alpha}, V_{1}, V_{2}, \\
\text { then reject } H_{0} \\
\text { All the } \\
\text { independent } \\
\text { variables are } \\
\text { good at } \\
\text { explaining the } \\
\text { dependent } \\
\text { variable at the } \\
95 \text { percent } \\
\text { confidence } \\
\text { level. }\end{array}$ \\
\hline Park test & $\begin{array}{l}H_{0}: \alpha_{1}=\alpha_{2}=\alpha_{3} \\
\quad=\alpha_{4}=\alpha_{5}=0\end{array}$ & $\begin{aligned} F^{*} & =\frac{E S S / d f}{R S S / d f} \\
F^{*} & =\frac{2.460 / 5}{16566.787 / 24} \\
F^{*} & =\frac{0.492}{690.283} \\
F^{*} & =0.001\end{aligned}$ & $\begin{array}{l}F_{\alpha}, V_{1}, V_{2} \\
0.05, K-1, \\
N-K \\
0.05,5,24 \\
=2.62\end{array}$ & $\begin{array}{l}F^{*}<F_{\alpha}, V_{1}, V_{2}, \\
\text { then accept } \\
H_{0} \text {. All } \\
\text { independent } \\
\text { variables are } \\
\text { not good in } \\
\text { explaining } \\
\text { dependent } \\
\text { variables at the } \\
95 \text { percent } \\
\text { confidence } \\
\text { level. }\end{array}$ \\
\hline
\end{tabular}


INTERNATIONAL JOURNAL OF ACADEMIC RESEARCH IN BUSINESS AND SOCIAL SCIENCES Vol. 9, No. 11, November, 2019, E-ISSN: 2222-6990 @ 2019 HRMARS

\begin{tabular}{|c|c|c|c|c|}
\hline $\begin{array}{c}\text { Glejser } \\
\text { test }\end{array}$ & $\begin{array}{l}H_{0}: \alpha_{1}=\alpha_{2}=\alpha_{3} \\
\quad=\alpha_{4}=\alpha_{5}=0 \\
H_{1}: \alpha_{t} \neq 0\end{array}$ & $\begin{aligned} F^{*} & =\frac{E S S / d f}{R S S / d f} \\
F^{*} & =\frac{0.001 / 5}{1.937 / 24} \\
F^{*} & =\frac{0.000}{0.081} \\
F^{*} & =0.001\end{aligned}$ & $\begin{array}{l}F_{\alpha}, V_{1}, V_{2} \\
0.05, K-1, \\
N-K \\
0.05,5,24 \\
=2.62\end{array}$ & $\begin{array}{l}F^{*}<F_{\alpha}, V_{1}, V_{2}, \\
\text { then accept } \\
H_{0} \text { All } \\
\text { independent } \\
\text { variables are } \\
\text { not good in } \\
\text { explaining } \\
\text { dependent } \\
\text { variables at the } \\
\text { 95 percent } \\
\text { confidence } \\
\text { level. }\end{array}$ \\
\hline
\end{tabular}

\section{Multicollinearity}

To test the multicolinearity problem, a test using the Pearson correlation coefficient value needs to be done. It is important to know whether there is a serious problem with multicollinearity or serious multicollinearity problems.

\section{Correlation Pearson}

The results obtained by using the Pearson correlation coefficient are as follows:

$$
\begin{aligned}
& \operatorname{Corr}\left(B D_{t}, I_{t}\right)=0.350 \\
& \operatorname{Corr}\left(B D_{t}, N S_{t}\right)=0.185 \\
& \operatorname{Corr}\left(B D_{t}, R E E R_{t}\right)=0.411 \\
& \operatorname{Corr}\left(B D_{t}, R I R_{t}\right)=0.260 \\
& \operatorname{Corr}\left(I_{t}, N S_{t}\right)=-0.045 \\
& \operatorname{Corr}\left(I_{t}, R E E R_{t}\right)=0.198 \\
& \operatorname{Corr}\left(I_{t}, R I R_{t}\right)=-0.124 \\
& \operatorname{Corr}\left(N S_{t}, R E E R_{t}\right)=-0.255 \\
& \operatorname{Corr}\left(N S_{t}, R I R_{t}\right)=-0.197 \\
& \operatorname{Corr}\left(R E E R_{t}, R I R_{t}\right)=0.404
\end{aligned}
$$

As a result of this correlation analysis, it shows that independent variables have significant relationships with each other at a 95 percent confidence level. Based on this model, it is also found that the $R^{2}$ value is equal to 0.718 which is greater than the value of $\operatorname{Corr}\left(B D_{t}, I_{t}, N S_{t}, R E E R_{t}, R I R_{t}\right)$. Therefore, when $R^{2}>\operatorname{Corr}\left(B D_{t}, I_{t}, N S_{t}, R E E R_{t}, R I R_{t}\right)$ this causes a non-serious multicollinearity problem. 


\section{Conclusion}

In conclusion, the analysis of this study is important to know whether the macroeconomic variables used are budget deficit, investment, national saving, real effective exchange rate and real interest rate directly or indirectly affecting economic growth in Malaysia. Therefore, the results of the research findings show that all the factors used affect the growth of the economy but at different levels of confidence where the budget deficit is significant at 93 percent confidence level, investment at 32 percent confidence level, national saving at the level of confidence 56 percent, and real effective exchange rate as well as real interest rate respectively at the 99 percent and 18 percent confidence level respectively. The findings are also based on the methodology or methodology used, taking into account economic criteria, statistical criteria, and econometric criteria. The findings in this study are seen to provide good input to the Malaysian government to make more detailed plans towards achieving the goal of becoming a high-income and sustainable country by the year 2020 .

\section{References}

Arestis, P., \& Resende, M. F. C. (2015). Fiscal policy and the substitution between national and foreign savings. Journal of Post Keynesian Economics, 37(3), 436-458.

Barro, R. J. (1974). Are government bonds net wealth? Journal of political economy, 82(6), 10951117.

Cebula R. J., Chao-Shun Hung and Neela D. Manage (1996). Ricardian Equivalence, Budget Deficits and Saving in the US, 1955: 1-1991:4. Applied Economics 1996,3,525-528.

Eisner, R. (1994). National saving and budget deficits. The review of economics and statistics, 181186.

Gale, W. G., \&Orszag, P. R. (2004). Budget deficits, national saving, and interest rates. Brookings Papers on Economic Activity, 2004(2), 101-210.

Habib, M. M., Mileva, E., \&Stracca, L. (2016). The real exchange rate and economic growth: revisiting the case using external instruments. Journal of International Money and Finance, 73, 386-398.

Haq, A. U. (2012). Impact of investment activities on economic growth of Pakistan. Business and Management review, 2(1), 92-100.

Hoover, D. K. (1992). Low US Saving: Increase It By Reducing The Federal Deficits, Business Economics, Jan 1992, vol. 27.

Jagadeesh, D. (2015). The Impact of Savings in Economic Growth: An Empirical Study Based on Botswana. International Journal, 10.

Jelilov, G. (2016). The Impact Of Interest Rate On Economic Growth Example Of Nigeria. African Journal of Social Sciences, 51-64.

Jilani, S., \& Sheikh, S. A. (2013). Determinants of national savings in Pakistan: An exploratory study. Asian Social Science, 9(5), 254.

Yan, L. S. (1993). National Saving and the Investment Gap: A Further Review in terms of Desegregation of the Domestic and Foreign Investment, First Malaysia National Conference on Savings, July 8-10, Kuala Lumpur. 
Nurudeen, A. (2010). Saving-economic growth nexus in Nigeria, 1970-2007: Granger causality and co-integration analyses. Review of economic and business studies, 3(1), 93-104.

Ogbokor, C. A., \&Samahiya, O. M. (2014). A time series analysis of determinants of savings in Namibia.

Ping, H. U. A. (2011). The economic and social effects of real exchange rate- Evidence from the Chinese provinces. In International Conference on Social Cohesion and Development.

Pradhan, G., \& Upadhyaya, K. P. (2001). The impact of budget deficits on national saving in the USA. Applied Economics, 33(13), 1745-1750.

Rodrik, D. (2008). The real exchange rate and economic growth. Brookings papers on economic activity, 2008(2), 365-412.

Saad, W., \& Kalakech, K. (2009). The Impact of Budget Deficits on Money Demand: Evidence from Lebanon. Middle Eastern Finance and Economics, 3, 65-76.

SadonoSukirno\& Hassan, M. A. G. (1999). Makroekonomi: Teori, MasalahdanDasarkerajaan. Petaling Jaya: Prentice Hall.

Sial, M. H., Hashmi, M. H., \& Anwar, S. (2010). Role of investment in the course of economic growth in Pakistan. World Academy of Sciences, Engineering and Technology, 4(6), 160.

Tang, C. F. (2008). A re-examination of the relationship between electricity consumption and economic growth in Malaysia. Energy Policy, 36(8), 3077-3085.

Turan, G., \&Gjergji, O. (2014). What is the impact of savings on growth? The case of a small open economy (Albania). Mediterranean Journal of Social Sciences, 5(13), 360.

Udoka, C. O., \& Anyingang, R. A. (2012). The effect of interest rate fluctuation on the economic growth of Nigeria, 1970-2010. International Journal of Business and Social Science, 3(20).

William, D. N. (1996). Budget Deficit and National Saving. March-April Challenge, Journal Economics Perspectives, 45-49. 